\section{Prevention of coronary heart disease}

SIR,-Surgeon Captain T L Cleave and Dr W W Yellowlees (29 May, p 1340) both remain unaware of, or choose to ignore, the fact that the fat of the intensively reared animals that they get from their butchers differs from that eaten by hunter-gatherers at the time of Moses and by nomadic peoples like the Masai today. My colleagues and I have described these differences, ${ }^{1-4}$ World Medicine has reviewed them, ${ }^{5}$ and we have written a general book on the subject ${ }^{6}$; the same query on animal fats was raised and answered in the Lancet five years ago.?

Body tissues contain two distinct types of lipid(a) structural lipid that forms cell membranes and is rich in the polyunsaturated fats (PUFA) that provide membrane integrity ${ }^{8}$ and fluidity, ${ }^{9}$ and (b) storage fat that acts as an energy source and is rich in the triglycerides of saturated, non-essential fatty acids. The first type changes in composition only under extreme deprivation; the second is very responsive to dietary change.

Free-living animals and nomadic herds build muscle, which is a rich source of structural lipid they accumulate only small amounts of carcass storage fats. 14610 This is what Moses ate, what the hunters and gatherers ate and still eat, and doubtless what turned up at Smithfield after the drovers had marched their cattle and geese from Wales in the time of Queen Victoria. Modern intensive farming methods in which the animal are fed on high-energy foods and deprived of exercise produce pathological tissues loaded with saturated fat (see figure) and deficient in the muscle cells that carry PUFA in their membranes. The ratio of non-essential fatty acids to PUFA in free-living animals is about $2: 1$ and in the modern domestic animal about 50:1.1 $\mathrm{Dr}$ Yellowlees also omits to mention that the Masai and Samburu mix blood with their milk and thus consume a rich source of PUFA in addition to the non-essential acids of the milk fat. Furthermore, the blood fatty acids of communities who eat free-living animals reflect their high degree of polyunsaturation. ${ }^{11}$

As far as the involvement of diet in coronary hear disease is concerned, one would not deny that dietary constituents other than fats have changed and are changing, and that the time scales were different for different constituents. Indeed, we

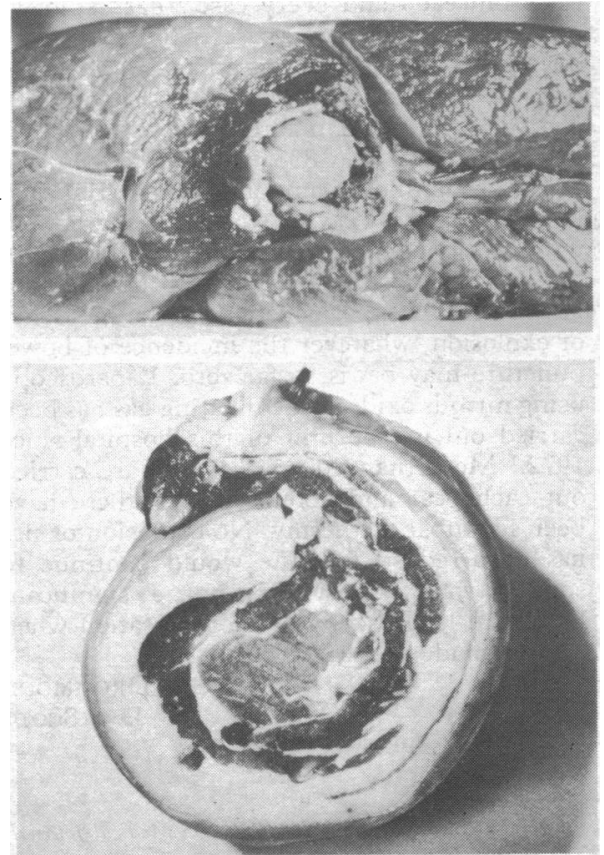

Above: Moses' or hunter-gatherers' or early UK meat. Beiow: from 1970s UK supermarket for comparison. From Crawford and Crawford. ${ }^{6}$ have stressed that one cannot discuss one item without the other because of the metabolic interactions between sugars, carbohydrates, fats, and amino-acids. ${ }^{8}$ However, fats do have a special significance because of their role in the construction of cell membranes and because they include essential PUFA ${ }^{12}$ which cannot be made in the body. Most are familiar with the notion of protein quality being dependent on the balance of essential and non-essential amino-acids. The same applies to structural lipids, which are built with essential (polyunsaturated) and non-essential fatty acids. In effect, what the nutritional experiments have shown is that the wrong kind of protein can affect body growth and the wrong kind of fat can affect arterial growth. The blood platelet as well as the arterial wall is also influenced by lipid quality. ${ }^{13}$

I would agree with Dr Yellowlees that $\mathrm{COMA}^{14}$ did not make any recommendations regarding the essential fats, even though Sinclair had discussed their involvement some time ago. ${ }^{1516}$ For me, the COMA report was unsatisfactory: their brief was to discuss the relationship between diet and coronary artery disease, but the report did not consider the part played by essential lipid nutrients used in the growth, maintenance, and repair of arteries. This is directly analogous to an attempt to relate diet to marasmus or kwashiorkor without reference to the essential aminoacids. How can one discuss diet and a disease process without discussing the "essential" nutrients involved?

On the other hand, the Joint Working Party's report $^{17}$ appears to me to give advice that is sensible in the light of present knowledge. Dr Yellowlees may, of course, ignore it and eat his sugary saturated high teas, eggs, and butter in quantity, but that is irrelevant, for students of the subject are more concerned with future generations than our own. He should remember that the old Scot did not live on marbled beef.

\section{Michael Crawford}

Department of Biochemistry,

作位e,

Zoological Society of London

Loological Societ

1 Crawford, M A, Lancet, 1968, 1, 1329

2 Crawford, $M$ A, et al, International fournal of Bio chemistry, 1970, 1, 295.

International fournal $M$ M, and Woodford, $M$ H International fournal of Biochemistry, 1970, 1, 654.
Crawford, M A, in Proceedings of the Third World Conference on Animal Production, ed R L Reid, p 21 . Sydney, University Press, 1975.

s W 21 . Sydiney, University Press, 1975.

- Crawford, M A, and Crawford, S M, What We Eat Today. London, Spearman, 1972

7 Crawford, M A, Lancet, 1, 1419.

Houtsmuller, U M T, in Dietary Lipids and Postnatal Development, ed C Galli et al, p 145. New York, Raven Press, 1973.

Chapman, D, in Lipids, Malnutrition and the Developing Brain, ed K Elliot and J Knight, p 31 . Am, dam, Associated Scientific Publishers, 1972 .
10 Ledger, H P, in Symposia of the Zoological Society of
London No 21. New York and London, Academic London No

11 Crawford, M A, Crawford, S M, and B Crawford, M A, and Sinclair, A J, in Lipids, Malnutrition and the Developing Brain, ed $\mathrm{K}$ Elliot and $J$ Knight, p 267. Amsterdam, Associated Scientific

13 The Role of Fats in Human Nutrition, ed A J Vergroesen. New York and London, Academic Press,

14 Department of Health and Social Security, Diet and Coronary Heart Disease. London, HMSO, 1974.

of London No 21, p 275. New York and London,
ond Academic Press, 1968

16 Sinclair, H M, in Lipid Pharmacology, ed R Paoletti, 17 237. New York, Academic Press, 1964

Joint Working Party, fournal of the Royal College of
Physicians of London, 1976, 10, 213.

SIR,-Dr W W Yellowlees (29 May, p 1340) refers to the high intake of cholesterol in the Masai and Samburu and their apparent nondevelopment of arteriosclerotic disease. My recent work $^{1}$ shows that in fact their low serum cholesterol level is present in these tribes only when they are living in their rural state. When they change their life style, with all that that entails in variation in personal responsibility and exercise levels as well as other unknown factors, their serum cholesterol rises rapidly. It is not possible, in my opinion, to correlate serum cholesterol directly with dietary intake.

London $\mathrm{N} 1$

JosÉ DAY

'Day, J, et al, Atherosclerosis, 1976, 23, 357.

\section{Fluid therapy in malaria}

SIR,-I read with considerable interest Col A P Hall's excellent review article on the treatment of malaria (7 February, p 323) and would like to make the following comment.

I certainly agree with the statement that excessive fluid administration in malaria may lead to pulmonary oedema because of delayed response to water load in some patients. ${ }^{1}$ However, since malarial patients can be either hypovolaemic, hypervolaemic, or normovolaemic, depending on the stage of the disease and the history of prior fluid administration, ${ }^{2}$ to make a generalisation that total fluid intake should not exceed $1500 \mathrm{ml} /$ day may be too extreme and may be hazardous in dehydrated patients. Hypovolaemia is in fact one among the mechanisms responsible for renal failure in malaria. ${ }^{2}$ In the presence of volume deficit and blood hyperviscosity, adequate hydration in an attempt to improve haemodynamics is desirable. In this instance $1500 \mathrm{ml}$ of fluid, as suggested in the article, may be too small. In my experience a higher amount of fluid of the order of $3000 \mathrm{ml} /$ day can be safely given to malarial patients who do not appear clinically overhydrated, with a small dose of frusemide administered intravenously at intervals. Diuresis is assured, fluid overload can be avoided, and renal function is not compromised. Salt and water administration and frusemide therapy are known to offer protection against renal failure, ${ }^{3}$ which is not uncommon in malaria in our unit.

\section{Visith SITPRIJA}

Department of Medicine,

School

Bangkok, Thailand

${ }^{1}$ Miller, L H, et al, Annals of Tropical Medicine and Parasitology, 1967, 61, 265.

' Sitprija, V, et al, Nephron, in press. 1971, 47, April suppl, p 7.
.

\section{Unexplained hepatitis following} halothane

SIR,-I read with interest the excellent article by $\mathrm{Dr}$ B Walton and others on unexplained hepatitis following halothane (UHFH) (15 May, p 1171).

Like most clinical anaesthetists, over the years I have followed the halothane and hepatitis controversy with interest. I have always felt that the "sensitivity reaction to halothane" hypothesis as a cause of hepatitis is not based on very firm ground because of the many hundreds of thousands of halothane anaesthetics administered compared with the low incidence of UHFH and the fact that in general anaesthetic practice it is virtually impossible to give a halothane-free anaesthetic because of the impossibility of finding a 